\title{
Spatial variability of forage yield and soil physical attributes of a Brachiaria decumbens pasture in the Brazilian Cerrado
}

\author{
Cristiano Magalhães Pariz ${ }^{1}$, Morel de Passos e Carvalho ${ }^{1}$, Carlos Alessandro Chioderoli $^{1}$, \\ Fernando Takayuki Nakayama ${ }^{1}$, Marcelo Andreotti ${ }^{1}$, Rafael Montanari ${ }^{1}$ \\ 1 Universidade Estadual Paulista "Júlio de Mesquita Filho", Faculdade de Engenharia, Caixa Postal 31, 15385-000, Ilha Solteira, SP, \\ Brasil.
}

ABSTRACT - The objective of this study was to analyze variability, linear and spatial correlations of forage dry mass yield (FDM) and dry matter percentage (DM\%) of Brachiaria decumbens with the bulk density (BD), gravimetric (GM) and volumetric (VM) moisture, mechanical resistance to penetration (RP) and organic matter content (OM), at depths $1(0-0.10 \mathrm{~m})$ and $2(0.10-0.20 \mathrm{~m})$, in a Red Latosol (Oxisol), in order to select an indicator of soil physical quality and identify possible causes of pasture degradation. The geostatistical grid was installed to collect soil and plant data, with 121 sampling points, over an area of 2.56 ha. The linear correlation between FDM $\times$ DM\% and FDM $\times$ BD2 was low, but highly significant. Spatial correlations varied inversely and positively, respectively. Except for DM\% and BD, at both depths, the other attributes showed average to high variability, indicating a heterogeneous environment. Thus, geostatistics emerges as an important tool in understanding the interactions in pasture ecosystems, in order to minimize possible causes of degradation and indicate better alternatives for soil-plant-animal management. The decrease in FDM and increased BD1 are indicators of physical degradation (compaction) of Red Latosol (Oxisol), particularly in the places with the highest concentration of animals and excessive trampling, in Cerrado conditions, in the municipality of Selvíria, Mato Grosso do Sul State, Brazil.

Key Words: bulk density, geostatistics, gravimetric and volumetric moisture, mechanical resistance to penetration, organic matter

\section{Introduction}

The importance of pastures in cattle production in Brazil is related, among other factors, to its low production cost (Santos et al., 2009). Nevertheless, the recovery of degraded areas by using adequate management techniques - which depend on a better understanding of the involved mechanisms and the limits for sustainable use - is one of the paths to promoting increased beef production (Páscoa \& Costa, 2007).

The loads or mechanical pressures exerted by cattle trampling on the ground, particularly on bare soil, can lead to medium and long-term changes in the physical properties of that soil, usually resulting in superficial compaction, characterized mainly by increased bulk density (Bertol et al., 2006). Therefore, bulk density is important in agricultural studies due to its close relationship to water and oxygen storage and movement. It can also indicate possible compaction (Kiehl, 1979; Reichert et al., 2009). High mechanical resistance of soil to penetration can limit root elongation and endanger root growth, and consequently plant development (Stolf, 1991; Reichert et al., 2009).

Thus, characterizing spatial variability of agricultural soil, combined with other statistical decision-making techniques, can contribute to more cost-effective and environmentally sustainable cattle raising. In this context, kriging is a geostatistical method that generates maps of a given attribute for non-sampled soil in unobserved locations (Páscoa \& Costa, 2007). The use of this method aims to detail the spatial variability of the soil's physical and chemical attributes, as well as crop yield (Lima et al., 2007).

Thereupon, the objective of the study was to analyze the viability of plant attributes (forage dry matter yield and relative dry matter) and soil attributes (bulk density, gravimetric moisture, volumetric moisture, mechanical resistance to penetration and organic matter), and define the linear and spatial correlations between plant attributes in order to establish a soil physical quality indicator that can reveal the possible causes of degradation of Brachiaria decumbens pastures at the study location. 


\section{Material and Methods}

The experiment was carried out in 2008 at Fazenda de Ensino, Pesquisa e Extensão (FEPE), belonging to the Faculdade de Engenharia, Campus of Ilha Solteira (FE/ Unesp), Animal Production area, located in the municipality of Selvíria, state of Mato Grosso do Sul (latitude $20^{\circ} 22^{\prime} 31^{\prime \prime S}$ and longitude $51^{\circ} 25^{\prime} 15^{\prime \prime} \mathrm{W}$ ), with average precipitation of $1.370 \mathrm{~mm}$ and average annual temperature of $24.1^{\circ} \mathrm{C}$. Climate type is Aw according to the Köppen classification, characterized as tropical humid, with rainy summers and dry winters (Figure 1).

The soil in the area is a typical medium-texture Red Latosol (Oxisol) A moderate, hypodystrophic, alic, caulinitic, hypoferric, very deep, moderately acid, according to the Embrapa (2006) classification, with $410 \mathrm{~g} / \mathrm{kg}$ of sand, $70 \mathrm{~g} / \mathrm{kg}$ of silt and $520 \mathrm{~g} / \mathrm{kg}$ of clay at $0-0.20 \mathrm{~m}$ of depth. The initial chemical attributes of the soil, assessed respectively at the depths of $0.0-0.10$ and $0.10-0.20 \mathrm{~m}$, were: $\mathrm{pH}\left(\mathrm{CaCl}_{2}\right)=$ 4.9 and $4.7 ; \mathrm{H}+\mathrm{Al}=26$ and $22 \mathrm{mmol}_{\mathrm{c}} / \mathrm{dm}^{3} ; \mathrm{P}$ (resin) $=10$ and $5 \mathrm{mg} / \mathrm{dm}^{3} ; \mathrm{K}^{+}=0.6$ and $0.1 ; \mathrm{Ca}^{2+}=9$ and $7 ; \mathrm{Mg}^{2+}=4$ and $3 \mathrm{mmol}_{\mathrm{c}} / \mathrm{dm}^{3}$; and $\mathrm{V}=34$ and $31 \%$. The Brachiaria decumbens pasture was implemented 33 years earlier (1978), and has been managed under continuous stocking (mean stocking rate of 1.5 UA in that period) for Guzerá cattle raising, receiving liming and fertilization during implementation and rehabilitation 23 years earlier (1988). It is currently in a stage of moderate degradation, with losses in productivity and quality, broadleaf weeds and soil compaction. At the time of data collection (March 29, 2008), the pasture had been deferred since February 1, 2008.

The directions of the Cartesian axes for the experimental geostatistical grid were defined in an area located at the center of the pasture under study. Thus, the $\mathrm{x}$-axis was set flat, whereas the y-axis was on a slope. Grid consisted of a total of 121 sampling points, distributed over an area of 2.56 ha $(160 \times 160 \mathrm{~m})$, with average slope of $0.025 \mathrm{~m} / \mathrm{m}$.

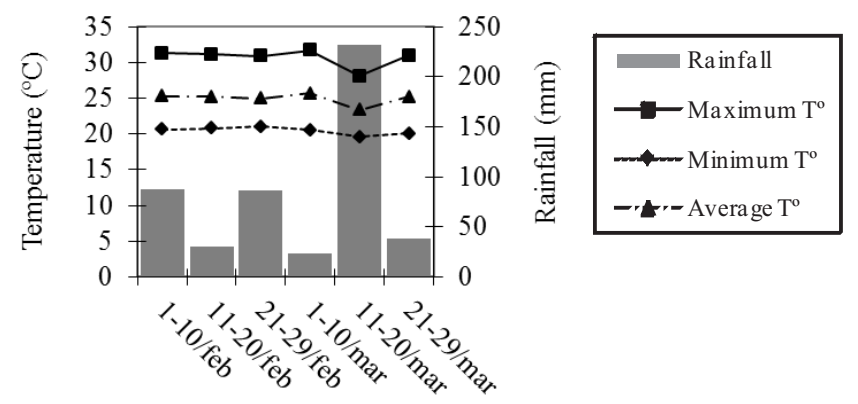

Period - day/month (2008)

Figure 1 - Rainfall and maximum, minimum and average temperatures for the experimental period.
Sampling points were spaced $20 \mathrm{~m}$ apart in the large grid and in the refined grid, with three swaths at the center of the grid (7.5, 5.0 and $7.5 \mathrm{~m}$, respectively), horizontally and vertically. The refined grid was set up in order to detect ranges of spatial dependence for spacings smaller than those of the large grid (Figure 2).

The soil attributes obtained around each sampling point were: bulk density (BD), gravimetric moisture (GM), volumetric moisture (VM), mechanical resistance to penetration (RP) and organic matter (OM) level, collected at depths of 0.0-0.10 and 0.10-0.20 m, and identified according to collection depth: a) 0-0.10 m: BD1, GM1, VM1, RP1 and OM1; b) 0.10-0.20 m: BD2, GM2, VM2, RP2 and OM2.

The methodology employed to determine soil physical attributes was that given by Embrapa (1997). The samples used to determine gravimetric moisture were removed directly from the pits dug to determine bulk density, using the volumetric ring method. Mechanical resistance to penetration was obtained using an impact penetrometer (model Planalsucar/IAA/Stolf), calculated using the expression given by Stolf (1991):

$\mathrm{RP}=\{5.581+6.891 \times[\mathrm{N} /(\mathrm{P}-\mathrm{A}) \times 10]\} \times 0.0981$,

in which: $\mathrm{RP}=$ soil mechanical resistance to penetration (MPa); $\mathrm{N}=$ number of impacts made with the penetrometer hammer to obtain the reading; and $\mathrm{A}$ and $\mathrm{P}=$ readings before $(\mathrm{A})$ and after $(\mathrm{P})$ the impacts $(\mathrm{cm})$. Volumetric moisture (VM) was calculated according to the following expression: $\mathrm{VM}=\mathrm{GM} \times \mathrm{BD}$

in which: $\mathrm{VM}=$ volumetric moisture $\left(\mathrm{m}^{3} / \mathrm{m}^{3}\right) ; \mathrm{GM}=$ gravimetric moisture $(\mathrm{kg} / \mathrm{kg})$; and BD = bulk density $\left(\mathrm{kg} / \mathrm{dm}^{3}\right)$.

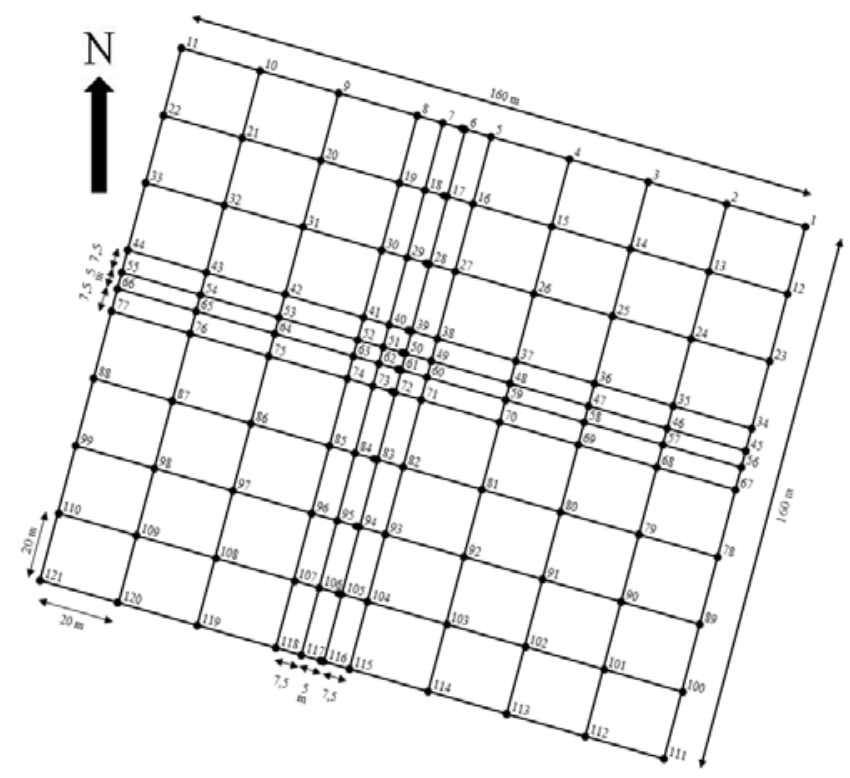

Figure 2 - Scheme of the experimental grid placed on the pasture, representing the 121 sampling points and their respective spacing. 
The plant attribute collected in the field was the green matter yield of Brachiaria decumbens forage, in the blossoming stage, transformed into forage dry matter (FDM) yield through oven drying at $65^{\circ} \mathrm{C}$ until reaching constant mass. The useful area for collection of this attribute was $1 \mathrm{~m}^{2}$, assessed with the aid of a metal square placed at the center of the sampling point, and cutting height was $0.15 \mathrm{~m}$. Results were extrapolated to kg/ha. The percentage of dry matter expressed as relative dry matter (rDM) was determined as well.

The traditional descriptive analysis was carried out for each attribute studied. To test the hypothesis of normality, or lognormality, the Shapiro-Wilk test (1965) was carried out at $1 \%$ significance. The correlation matrix was set up to perform the simple linear correlations for the combinations, two by two, between the attributes studied. Geostatistical analysis was performed using Gamma Design Software 7.0 (GS+, 2004). The semivariogram models were fitted by selecting the lowest value of the sum of squared residuals (SSR) and the decision on the model was made through cross validation analysis. In cases of undefined stationarity of a given attribute, trends were removed from the data by using the polynomial regression technique. Hence, backtransformed attributes were preceded by the \# symbol. Spatial dependence analysis (SDA) was performed according to the following expression:

$\mathrm{SDE}=[\mathrm{C} /(\mathrm{C}+\mathrm{Co})] .100$,

in which: $\mathrm{SDE}$ = spatial dependence evaluator; $\mathrm{C}$ = structural variance; and $\mathrm{C}+\mathrm{Co}=$ threshold. So, the interpretation proposed for the SDE was the following: SDE $\leq 25 \%$ indicates weak spatial variable dependence; $25 \%<$ SDA $\leq 75 \%$ indicates moderate spatial variable dependence; and SDA $>75 \%$ indicates strong spatial variable dependence (GS+, 2004; Lima et al., 2007). Cross validation was used to evaluate alternative simple semivariogram models, for kriging modeling. In that process, each point within the spatial domain is removed individually, with its value estimated as if it did not exist. Thus, it is possible to construct a graph with estimated values versus those observed for all points. The correlation coefficient (r) between these values reflects the efficiency of the fit, given by the SSR technique, representing the linear regression equation in question. A perfect fit would have a regression coefficient equal to 1 and the best-fit line would coincide with the perfect model, with the linear coefficient equal to 0 and the angular coefficient equal to 1 (GS+, 2004). Thus, working to obtain the ideal number of neighbors, kriging maps were obtained through interpolation, for spatial dependence analysis between the attributes.

\section{Results and Discussion}

The variability of an attribute can be classified according to the magnitude of its coefficient of variation (CV) (Lima et al., 2007). Forage dry matter (FDM) yield and organic matter levels at 0-0.10 m (OM1) and 0.10-0.20 m (OM2) deep were highly variable, while relative dry matter (rDM), bulk density at 0-0.10 m (BD1) and 0.10-0.20 m (BD2) showed low variability (Table 1 ). The remaining physical attributes of the soil showed medium variability. In general, the coefficients of variation for attributes bulk density (BD) and mechanical resistance to penetration (RP) were in the same range as those described by Lima et al. (2009), Lima et al. (2007) and Colet et al. (2009), whereas the OM level was higher than those reported by Cavalcante et al. (2007) and Cavallini et al. (2010), obtained at the same location.

The spatial variability of the soil - horizontal and/or vertical - results from the interaction of the factors and processes involved in its formation (Lima et al., 2007). Thus, the action exerted by animal grazing represents a decisive fact in increasing its spatial heterogeneity (Bertol et al., 2006; Páscoa \& Costa, 2007). Therefore, both for bulk density (BD) and mechanical resistance to penetration (RP), combined with the fact of possible superficial soil compaction by animal trampling, the higher coefficients of variation found at the depth of $0-0.10 \mathrm{~m}$ attest that over the years grazing increased soil surface heterogeneity. In contrast, whenever a given variable has a normal distribution frequency, the measure of central tendency that best represents it is the mean. Thus, forage dry matter (FDM) yield showed a frequency distribution tending towards normal, with mean, maximum and minimum values of 2,184, 3,800 and $758 \mathrm{~kg} / \mathrm{ha}$, respectively (Table 1 ) - the latter being similar to the mean reported by Santos et al. (2007) in a dark Red Latosol with $B$. decumbens pasture 20 years after rehabilitation. Therefore, the pasture under study was likely degraded, given the lack of regrowth vigor and natural soil coverage capacity, as it had been deferred for approximately 60 days at the moment of harvest. Additionally, there was a high incidence of weeds (magnoliopsida; broadleaf), which is another indicator of degradation of this pasture.

The frequency distribution was normal for bulk density at depth 2 (Table 1), similar to the data found by Lima et al. (2007), and tending towards normal for density at $1 \mathrm{~m}$ deep, whereas Lima et al. (2009), Cavallini et al. (2010), Martins et al. (2009) and Rosa Filho et al. (2009) observed normality in these attributes at both depths. The mean values for bulk density at depths 1 and 2 showed a marked difference (1.59 and $1.54 \mathrm{~kg} / \mathrm{dm}^{3}$, respectively), while maximum values showed a greater interval (1.89 and $1.76 \mathrm{~kg} / \mathrm{dm}^{3}$, 
Table 1 - Initial descriptive statistical analysis of forage dry matter yield for Brachiaria decumbens and attributes of a Red Latosol (Oxisol)

\begin{tabular}{|c|c|c|c|c|c|c|c|c|c|c|}
\hline \multirow[t]{2}{*}{ Attribute $^{1}$} & \multirow[t]{2}{*}{ Mean } & \multirow[t]{2}{*}{ Median } & \multicolumn{2}{|c|}{ Valor } & \multirow{2}{*}{$\begin{array}{l}\text { Standard } \\
\text { deviation }\end{array}$} & \multirow[t]{2}{*}{ CV (\%) } & \multicolumn{2}{|c|}{ Coefficient } & \multicolumn{2}{|c|}{ Test Probability ${ }^{2}$} \\
\hline & & & Minimum & Maximum & & & Kurtosis & Asymmetry & $\operatorname{Pr}<w$ & FD \\
\hline \multicolumn{11}{|c|}{ Plant attributes } \\
\hline rDM (\%) & 33.75 & 34.09 & 27.27 & 42.42 & 2.82 & 8.4 & 0.032 & 0.176 & 0.452 & NO \\
\hline \multicolumn{11}{|c|}{ Soil physical attributes } \\
\hline BD1 $\left(\mathrm{kg} / \mathrm{dm}^{3}\right)$ & 1.59 & 1.58 & 1.32 & 1.89 & 0.11 & 6.9 & 0.177 & 0.110 & 0.039 & $\mathrm{TN}$ \\
\hline GM2 (kg/kg) & 0.14 & 0.14 & 0.09 & 0.18 & 0.02 & 12.0 & -0.214 & 0.033 & 0.257 & NO \\
\hline VM1 $\left(\mathrm{m}^{3} / \mathrm{m}^{3}\right)$ & 0.22 & 0.22 & 0.14 & 0.36 & 0.04 & 16.4 & 1.280 & 0.740 & 0.006 & $\mathrm{TN}$ \\
\hline VM2 $\left(\mathrm{m}^{3} / \mathrm{m}^{3}\right)$ & 0.22 & 0.21 & 0.13 & 0.30 & 0.03 & 13.4 & 0.442 & 0.387 & 0.037 & $\mathrm{TN}$ \\
\hline RP1 (MPa) & 3.031 & 3.002 & 1.900 & 4.613 & 0.587 & 19.4 & -0.579 & 0.273 & 0.110 & NO \\
\hline RP2 (MPa) & 3.323 & 3.353 & 2.163 & 4.405 & 0.408 & 12.3 & 0.562 & -0.140 & 0.244 & $\mathrm{NO}$ \\
\hline
\end{tabular}

${ }^{1}$ FDM: forage dry matter yield of Brachiaria decumbens; rDM: forage relative dry matter; BD, GM, VM, RP and OM, from 1 to 2 are, respectively, bulk density, gravimetric moisture, volumetric moisture, maximum resistance to penetration and the level of organic matter in the soil, in depth 1 (0.0-0.10 $\mathrm{m})$ and 2 (0.10-0.20 $\mathrm{m})$.

${ }^{2}$ FD: frequency distribution, with $\mathrm{NO}=$ normal type; $\mathrm{TN}=$ tending towards normal.

respectively). Nevertheless, mean bulk density values were similar to those reported by Silva et al. (2008) and Colet et al. (2009), remaining between 1.40 and $1.60 \mathrm{~kg} / \mathrm{dm}^{3}$, indicated by Reichert et al. (2003) and critical for medium texture soils. Maximum values were greater than $1.70 \mathrm{~kg} / \mathrm{dm}^{3}$, which can affect plant growth by physically impeding adequate root development according to Kiehl (1979) and Camargo \& Alleoni (1997), as well as the review by Reichert et al. (2009). Considering the optimal hydric interval for pastures, the critical BD for a Red Latosol is $1.43 \mathrm{~kg} / \mathrm{dm}^{3}$.

The extremely high pressure from compaction, caused by animal trampling and movement as compared with that exerted by farming implements (Cantarutti et al., 2001), evidenced that bulk density (BD) values (Table 1) were higher than those found by Cavallini et al. (2010), Martins et al. (2009) and Rosa Filho et al. (2009), who dealt with the no-till system (NTS) for B. brizantha, beans and soybean, respectively, in a Red Latosol dystroferric in the same locality. Spera et al. (2004), evaluating a distrofic Red Latosol, verified an increase in bulk density values at smaller depths than this study, and evidenced that animal trampling on pasture also caused a slight increase in bulk density on the surface layer, in a crop-livestock system (CLS), with annual winter pasture compared to areas used with perennial pastures followed by crop systems. In general, however, soil physical attributes did not significantly affect the productivity of the evaluated crops, while Sulc \& Tracy (2007) and Tracy \& Zhang (2007) showed a reduction in soil compaction in a CLS in the United States, compared with an exclusive livestock system.
During the collections of soil physical samples, increased rooting of $B$. decumbens pasture was observed on the surface layer (especially down to $0.05 \mathrm{~m}$ deep), denoting a likely difficulty in the development of those roots due to the possible physical impediment. Santos et al. (2007), evaluating the root production of that species in the profile of a dark Red Latosol after 20 years of rehabilitation, also observed that $32 \%$ of roots were found $0-0.05 \mathrm{~m}$ deep, while in pastures between one and seven years of age, distribution improved throughout the soil profile down to depth 1. According to Warren et al. (1986), soil compaction due to inadequate management practices alters soil physical attributes, leading to a reduction in root system development and pasture productivity.

The gravimetric moisture at depths of 0-0.10 m (GM1) and 0.10-0.20 m (GM2) showed frequency distributions tending toward normal and normal, respectively, with mean values of $0.14 \mathrm{~kg} / \mathrm{kg}$ at both depths. Volumetric moisture at depths of 0-0.10 m (VM1) and 0.10-0.20 m (VM2) showed frequency distributions tending toward normal with a mean value of $0.22 \mathrm{~m}^{3} / \mathrm{m}^{3}$ at both depths. These values are different from those reported by Martins et al. (2009) and Rosa Filho (2009), who presented increases in gravimetric and volumetric moisture, with higher values for these attributes, compared with the present study. The same was observed by Cavallini et al. (2010), which shows the ability of soil to store water under irrigated NTS, proving to be an excellent option for a soil and water conservation system. Thus, in agreement with Colet et al. (2009), gravimetric and volumetric moisture values indicated low water infiltration and retention capacity, due to the evident soil compaction, 
considering the rainfalls during the time of pasture deferment and sampling of attributes (Figure 1) and the values of bulk density (BD) and mechanical resistance to penetration (RP) (Table 1).

The ideal soil moisture condition for collection of data on mechanical resistance to penetration should be between the field capacity and a level at least 1/3 lower than field capacity, as defined by Kiehl (1979). In practical terms, this normally occurs whenever the soil shows volumetric moisture (VM) in microporosity between 0.33 and $0.22 \mathrm{~m}^{3} / \mathrm{m}^{3}$. Therefore, the data of the present study were collected at the minimum limit for soil volumetric moisture $-0.22 \mathrm{~m}^{3} / \mathrm{m}^{3}$ at both depths (Table 1 ). These results may be explained by the possible surface flow of water from the rainfalls that took place during the experimental period (Figure 1), due to the reduced infiltration as the result of the higher bulk density values at the depths of $0-0.10 \mathrm{~m}$ (BD1) and 0.10-0.20 m (BD2) (Table 1).

The mechanical resistance to penetration at the depths of 0-0.10 m (RP1) and 0.10-0.20 m (RP2) shows a normal type frequency distribution (Table 1 ) and the values of that attribute were similar to those reported by Martins et al. (2009) and Rosa Filho et al. (2009) in irrigated NTS, as well as those by Colet et al. (2009) B. decumbens pastures on a distrofic Yellow-Red Latosol. However, the values were higher when those authors used scarification, which significantly reduced the values of mechanical resistance to penetration, particularly at the depth of $0-0.20 \mathrm{~m}$. When using the classification of Arshad et al. (1996), it was observed that the mean values showed high resistance to root penetration at both depths (greater than 3.0 MPa), given that, in addition to depending on intrinsic factors (texture, structure and mineralogy), this attribute is highly dependent on soil moisture. Therefore, when very low, water is retained with greater tension in the pores, unleashing a predominance of solid-solid cohesive forces, and therefore leading to a considerable increase in mechanical resistance to penetration. The amplitude found between the minimum and maximum values of RP1 and RP2 (Table 1) corroborates Vieira et al. (2005), Cavallini et al. (2010), Martins et al. (2009) and Rosa Filho et al. (2009), demonstrating that, in general, regardless of farming activity (crop or livestock), Brazilian soils show high variability in this attribute.

Organic matter levels at the depths of 0-0.10 m (OM1) and 0.10-0.20 m (OM2) (Table 1) showed a frequency distribution tending toward normal, and despite the reduced depth level, remained within the 16 -to- $30 \mathrm{~g} / \mathrm{dm}^{3}$ range for medium texture soil, reported by Raij et al. (1997). However, reduced OM depths levels were also observed by Cavalcante et al. (2007), under different soil uses and managements although a lower level of this attribute was verified in areas under $B$. decumbens pasture, Cerrado and conventional tillage, being higher only in NTS. Cavallini et al. (2010) also observed the same behavior for this attribute under irrigated NTS, including similar mean levels.

The data on the correlation coefficients between the researched attributes (Table 2) were low, which is justified by the high number of observations $(n=121)$. The noteworthy significant correlations were forage dry matter $(\mathrm{FDM})$ yield $\times$ relative dry matter $(\mathrm{rDM})\left(\mathrm{r}=-0.296^{* *}\right)$ and FDM $\times$ bulk density at the depth of 0.10-0.20 m (BD2) $\left(\mathrm{r}=0.224^{*}\right)$, in which the former indicated a decreasing function between cause and effect, with increasing FDM as a function of decreasing $\mathrm{rDM}$, while the latter showed a positive correlation, indicating an increase in forage dry matter with the increased BD2. The literature features several research studies on the spatial distribution of physical attributes, and soil organic matter (OM) levels, correlated with grain productivity. However, there are few studies that discuss this effect on forage production for cattle grazing.

Table 2 - Linear correlation matrix between the forage dry matter yield of Brachiaria decumbens and the attributes of a Red Latosol (Oxisol)

\begin{tabular}{|c|c|c|c|c|c|c|c|c|c|c|c|}
\hline & \multicolumn{11}{|c|}{ Correlation coefficient $^{2}$} \\
\hline & $\mathrm{FDM}^{1}$ & rDM & BD1 & BD2 & GM1 & GM2 & VM1 & VM2 & RP1 & $\mathrm{RP} 2$ & OM1 \\
\hline rDM & $-0.296^{* *}$ & - & - & - & - & - & - & - & - & - & - \\
\hline BD1 & $-0.013^{\mathrm{ns}}$ & $0.072^{\mathrm{ns}}$ & - & - & - & - & - & - & - & - & - \\
\hline BS2 & $0.224^{*}$ & $-0.130^{\mathrm{ns}}$ & $-0.043^{\mathrm{ns}}$ & - & - & - & - & - & - & - & - \\
\hline GM1 & $0.034^{\mathrm{ns}}$ & $0.022^{\mathrm{ns}}$ & $-0.126^{\mathrm{ns}}$ & $0.084^{\mathrm{ns}}$ & - & - & - & - & - & - & - \\
\hline GM2 & $0.069^{\mathrm{ns}}$ & $0.006^{\mathrm{ns}}$ & $-0.040^{\mathrm{ns}}$ & $-0.080^{\mathrm{ns}}$ & $0.568^{* *}$ & - & - & - & - & - & - \\
\hline VM1 & $0.030^{\mathrm{ns}}$ & $0.054^{\mathrm{ns}}$ & $0.282^{* *}$ & $0.065^{\mathrm{ns}}$ & $0.911^{* *}$ & $0.519^{* *}$ & - & - & - & - & - \\
\hline VM2 & $0.142^{\mathrm{ns}}$ & $0.026^{\mathrm{ns}}$ & $-0.034^{\mathrm{ns}}$ & $0.320^{* *}$ & $0.597^{* *}$ & $0.874^{* *}$ & $0.551^{* *}$ & - & - & - & - \\
\hline RP1 & $-0.112^{\mathrm{ns}}$ & $0.117^{\mathrm{ns}}$ & $-0.115^{\mathrm{ns}}$ & $-0.137^{\mathrm{ns}}$ & $0.023^{\mathrm{ns}}$ & $0.177^{\mathrm{ns}}$ & $-0.021^{\mathrm{ns}}$ & $0.097^{\mathrm{ns}}$ & - & - & - \\
\hline R P 2 & $0.088^{\mathrm{ns}}$ & $0.003^{\mathrm{ns}}$ & $-0.124^{\mathrm{ns}}$ & $0.122^{\mathrm{ns}}$ & $0.253^{* *}$ & $0.194^{*}$ & $0.207^{*}$ & $0.216^{*}$ & $0.454^{* *}$ & - & - \\
\hline OM1 & $0.087^{\mathrm{ns}}$ & $-0.014^{\mathrm{ns}}$ & $-0.016^{\mathrm{ns}}$ & $0.144^{\mathrm{ns}}$ & $0.297^{* *}$ & $0.297^{* *}$ & $0.359^{* *}$ & $0.379^{* *}$ & $0.040^{\mathrm{ns}}$ & $0.176^{\mathrm{ns}}$ & - \\
\hline OM2 & $0.000^{\mathrm{ns}}$ & $0.080^{\mathrm{ns}}$ & $-0.182 *$ & $0.249^{* *}$ & $0.311^{* *}$ & $0.158^{\mathrm{ns}}$ & $0.231^{*}$ & $0.282^{* *}$ & $0.118^{\mathrm{ns}}$ & $0.235^{*}$ & $0.212^{*}$ \\
\hline
\end{tabular}

${ }^{1}$ FDM: forage dry matter yield of Brachiaria decumbens; rDM: forage relative dry matter; BD, GM, VM, RP and OM, from 1 to 2 are, respectively, bulk density, gravimetric moisture, volumetric moisture, maximum resistance to penetration and the level of organic matter in the soil, in depth $1(0.0-0.10 \mathrm{~m})$ and $2(0.10-0.20 \mathrm{~m})$. $2 * *, *$, ns. significant at 1 and $5 \%$ and non-significant, respectively. 
Nevertheless, Cavallini et al. (2010), while evaluating the forage dry matter of $B$. brizantha $\mathrm{cv}$. Marandu when destined for straw production under irrigated NTS, observed a positive correlation of FDM with bulk density (BD) at the depth of 0.20-0.30 m, using linear regression; in contrast, the correlation of FDM with mechanical resistance to penetration at the depth of 0.20-0.30 m (RP3) was inverse, due to adverse root growth conditions, given that Brachiaria spp. show high root concentration at greater depths if not overgrazed. This correlation was not observed in the present study, possibly due to the overgrazing cycle over the years, which, along with soil compaction, can explain the superficial rooting of $B$. decumbens.

Thus, forage dry matter (FDM) yield, as a function of relative dry matter (rDM) and bulk density at the depth of 0.10-0.20 m(BD2), could be estimated by using the following simple regression equations:

$\mathrm{FDM}=144,300 \times \mathrm{rDM}^{-1.205} \ldots \ldots .\left(\mathrm{r}^{2}=0.100, \mathrm{p}<0.01\right)$.

$\mathrm{FDM}=29,750-37,830 \times \mathrm{BD} 2+12,900 \times \mathrm{BD}^{2}$.

$\left(\mathrm{r}^{2}=0.086, \mathrm{p}<0.01\right)$.

The extreme values of relative dry matter (rDM), obtained in Table 1 (27.27 and 42.42\%), resulted, respectively, in the values of 2,687 and 1,578 kg/ha of forage dry matter yield (FDM). Bulk density values at $0.10-0.20 \mathrm{~m}$ (BD2) (1.31 and $1.76 \mathrm{~kg} / \mathrm{dm}^{3}$ ), respectively, resulted in 2,330 and 3,128 kg/ha. These facts may be explained by the understanding of environmental factors (availability of water, oxygen and nutrients, and plant phenological stage) regarding morphological and physiological changes, root biomass and vertical distribution of forage plant roots - due to low soil fertility in conjunction with the water deficit, the plant tends to increase its levels of lignin and other structural components of the cell wall (fiber), by raising rDM and reducing FDM due to the low growth rate. Nonetheless, despite the small number of roots found during soil sampling, at the depth of 0.10-0.20 m, from the minimum point of Eq. (2) $\left(\right.$ BD2 $\left.=1.466 \mathrm{~kg} / \mathrm{dm}^{3}\right)$, soil $/$ root contact may have increased the nutrient efficiency of nutrient absorption, and consequently increased FDM, as demonstrated by the positive correlation BD2 x OM2 $\left(r=0.249^{* *}\right)$ (Table 2). According to Hakansson et al. (1998), lower soil/root contact reduces the absorption of water and nutrients by the plant, and consequently reduces plant productivity. Root system length is very important to the absorption of nutrients that come into contact with the root by diffusion ( $\mathrm{P}$ and $\mathrm{K}$ ) and root interception $(\mathrm{Ca})$.

The statistical analysis of the krigings (Table 3) evidenced excellent semivariograms for attributes forage dry matter yield (\#FDM), bulk density at 0-0.10 m (BD1) and 0.10-0.20 m(BD2), gravimetric moisture at 0.10-0.20 m (\#GM2) and volumetric moisture at 0.10-0.20 m (\#VM2). Therefore, relative dry matter ( $\mathrm{rDM})$, gravimetric moisture at $0-0.10 \mathrm{~m}$ (GM1), volumetric moisture at 0-0.10 m (VM1), maximum resistance to penetration at $0-0.10 \mathrm{~m}$ (RP1) and $0.10-0.20 \mathrm{~m}$ (RP2), organic matter level at $0-0.10 \mathrm{~m}(\mathrm{OM} 1)$ and $0.10-0.20 \mathrm{~m}$ (OM2) showed a pure nugget effect, denoting the existence of a completely random spatial distribution. Therefore, it was evidenced that the distributions of \#FDM, BD1, BD2, \#GM2 and \#VM2 in space were not random, as their spatial dependence varied between 50.0 (\#FDM) and 99.9\% (BD1). Compared to the results obtained by Cavallini et al. (2010), due to the evaluation of different species (B. brizantha) and production systems (irrigated NTS), the latter showed an extreme superiority of FDM (mean 12,485 kg/ha) in relation to the present study, but with the same class of moderate spatial dependence (50.0\%).

The class of spatial dependence for bulk density at the depth of 0.10-0.20 m (BD2) (Table 3) was moderate as well (63.6\%), similar to the values obtained by Lima et al. (2007), Cavallini et al. (2010) and Rosa Filho et al. (2009), whereas the values for volumetric moisture at the depth of $0.10-0.20 \mathrm{~m}$ (\#VM2) and bulk density at the depth of 0-0.10 m (BD1) were high at 76.3 and $99.9 \%$, respectively, in agreement with those obtained by Martins et al. (2009), which showed a similar class of spatial dependence for the same attributes. Therefore, the total variation levels of forage dry matter

Table 3 - Parameters of the semivariograms fitted for forage dry matter yield of Brachiaria decumbens and some physical attributes of a Red Latosol (Oxisol)

\begin{tabular}{|c|c|c|c|c|c|c|c|c|}
\hline Attribute $^{1}$ & Model $^{2}$ & $\begin{array}{c}\text { Nugget } \\
\text { effect }\left(C_{0}\right)\end{array}$ & $\begin{array}{c}\text { Threshold } \\
\left(\mathrm{C}_{0}+\mathrm{C}\right)\end{array}$ & $\begin{array}{c}\text { Reach } \\
\left(\mathrm{A}_{0}\right)(\mathrm{m})\end{array}$ & $r^{2}$ & $\mathrm{SSR}^{3}$ & $\mathrm{SDE}^{4 \%} \%$ & $\begin{array}{c}\text { Class of } \\
\text { spatial dependence }\end{array}$ \\
\hline \#FDM (kg/ha) & esf & $2.433 .10^{5}$ & $4.867 .10^{5}$ & 164.3 & 0.977 & $1.360 .10^{9}$ & 50.0 & Moderate \\
\hline \multicolumn{9}{|c|}{$\gamma(\mathrm{h})$ simple of soil physical attributes } \\
\hline $\mathrm{BD} 2\left(\mathrm{~kg} / \mathrm{dm}^{3}\right)$ & esf & $2.570 .10^{-3}$ & $7.060 .10^{-3}$ & 21.4 & 0.665 & $2.698 .10^{-6}$ & 63.6 & Moderate \\
\hline \#GM2 (kg/kg) & esf & $7.800 .10^{-5}$ & $1.560 .10^{-4}$ & 26.5 & 0.609 & $1.471 .10^{-9}$ & 50.3 & Moderate \\
\hline \#VM2 $\left(\mathrm{m}^{3} / \mathrm{m}^{3}\right)$ & esf & $1.140 .10^{-4}$ & $4.810 .10^{-4}$ & 29.0 & 0.793 & $1.700 .10^{-8}$ & 76.3 & High \\
\hline
\end{tabular}

${ }^{1} \mathrm{FDM}$ : forage dry matter yield of Brachiaria decumbens; BD, GM and VM, from 1 to 2 are, respectively, bulk density, gravimetric moisture and volumetric moisture of soil in depths $1(0.0-0.10 \mathrm{~m})$ and $2(0.10-0.20 \mathrm{~m}) .{ }^{2}$ sf: spherical. ${ }^{3}$ SSR: sum of the squared residuals. ${ }^{4}$ SDE: spatial dependence evaluator. 
yield (\#FDM) and BD1 of 50.0 and 99.9\%, respectively, were explained by spatial dependence. For its part, the nugget effect attributed to casual errors was 50.0\% (\#FDM) and $0.01 \%$ (BD1). Thus, it can be inferred that BD1 showed the best semivariogram fitting, and also that the adjusted model was spherical for all attributes that showed spatial dependence (\#FDM, BD1, BD2, \#GM2 and \#VM2), in agreement with Cavallini et al. (2010), with the exception of GM2, which showed a pure nugget effect.

With regard to the ranges of spatial dependence (SDE) (Table 3), it was $164.3 \mathrm{~m}$ for forage dry matter (\#FDM) yield, and 35.1, 21.4, 26.5 and $29.0 \mathrm{~m}$ for bulk density at $0-0.10 \mathrm{~m}$ (BD1) and 0.10-0.20 m (BD2), gravimetric moisture at 0.10-0.20 m (\#GM2) and volumetric moisture at 0.10-0.20 m (\#VM2), respectively. These values were higher than those obtained by Lima et al. (2007) and Rosa Filho et al. (2009) and lower than those by Martins et al. (2009). Spatially, the krigings of attributes \#FDM, BD1, BD2 \#GM2 and \#VM2 are represented in Figure 3. In Figure 3b, with the increase in BD1 in the central, northwest and northeast regions (greater than $1.54 \mathrm{~kg} / \mathrm{dm}^{3}$ ), \#FDM (Figure 3a) was lower than $2,013 \mathrm{~kg} / \mathrm{ha}$, averaging $1,728 \mathrm{~kg} / \mathrm{ha}$. Likewise, kriging showed (Figure 3e) that the lowest \#VM2 values took place in the northeast regions, while in the kriging (Figure 3d), the reduction in the \#GMvalues occurred diagonally, from northwest to southeast.

However, as shown in Table 1, the values for volumetric moisture at 0.10-0.20 m (\#VM2) were much lower than those obtained by Cavallini et al. (2010) and Rosa Filho et al. (2009) in irrigated NTS, showing in a spatial manner the low water storage capacity of the soil under study.

According to the review by Carvalho et al. (2009), results of the impact from animal trampling in long-term georeferenced studies in pasture areas under different grazing conditions made it possible to identify the most frequented regions by the animals, by locating the areas with the highest values of mechanical resistance to penetration (RP) and lowest pasture height. In the present study, the locations with lowest forage dry matter (\#FDM) yield (Figure 3a) also had lower height pasture, representing the most frequented regions and those with the highest bulk density at 0-0.10 m (BD1) (Figure 3b), while RP data did not show spatial dependence.

In this context, cattle behavior under grazing - which among other things reflects their preference for certain regions of the terrain - may consist of several factors, among which: relief and topography (animal preference for higher areas of the terrain); availability, proximity and ease of access to drinking troughs and feeding troughs; supply and allowance of protein/energy supplements; factors that favor thermoregulation (shade and wind, for instance) and social behavior patterns (Bailey, 2005) are relevant to the present study. Thus, in the higher regions of the study area (central, north and northeast) a lower forage dry matter (\#FDM) yield was observed (lower than 2,013 kg/ha) (Figure 3a). In \#FDM lower than 1,823 kg/ha, the regions with the highest temporal concentration of animals and excessive trampling, known as resting place (where the cattle remain the longest) were observed, which in the study area comprised the drinking trough, tree shades and mineral supplementation trough (northeast region), and the vicinity of an old mineral supplementation trough (northwest region). Similar results were reported by Páscoa \& Costa (2007), who were also using the kriging geostatistical technique. Conversely, the proximity to the handling corral (southeast region) and the tracks set up in parallel at the borders of the south and west regions locations where there is normally a high traffic of people, which inhibits animal grazing - as well as superficial depositions of nutrients in the soil and the lower access of animals in lower regions (southwest and southeast), may all have contributed to the occurrence of higher \#FDM values.

According to Cantarutti et al. (2001), the pressure exerted on the soil by the trampling of animals in movement is quite greater than that from static animals, and in general, compaction from animal traffic occurs on the superficial layer. These statements were verified in the present study, in which bulk density at 0-0.10 m (BD1) was greater than $1.59 \mathrm{~kg} / \mathrm{dm}^{3}$ (Figure 3b) on the trail (path routinely taken by the cattle) from the old mineral supplementation trough (northwest region) to the resting spot (northeast region) and in the vicinity of the protein/energy supplementation trough during the dry season (southeast region), whereas bulk density at 0.10-0.20 m (BD2) (Figure 3c) showed significantly lower values in these regions. Thus, according to Laca (2008), the success of geostatistics as a support tool in defining grazing animal handling strategies depends also on the knowledge of their behavior, so as to better define the spatial arrangement of drinking/feeding troughs and shade. This will improve the use of available resources and lead animals to visit locations with lesser animal traffic, as repeated animal trampling at the same location can lead to dramatic changes in the physical conditions of the soil, limiting root system growth and pasture productivity.

In cross validation (Table 4), krigings confirmed that the bulk density at $0-0.10 \mathrm{~m}$ (BD1) provided the best semivariogram fit, showing the highest correlation coefficient $(r=0.530)$, with the linear coefficient (a) tending toward 0 and the angular coefficient (b) closer to 1 (0.773), as recommended by GS+ (2004). This may also be verified in comparison with the results of Cavallini et al. (2010), 


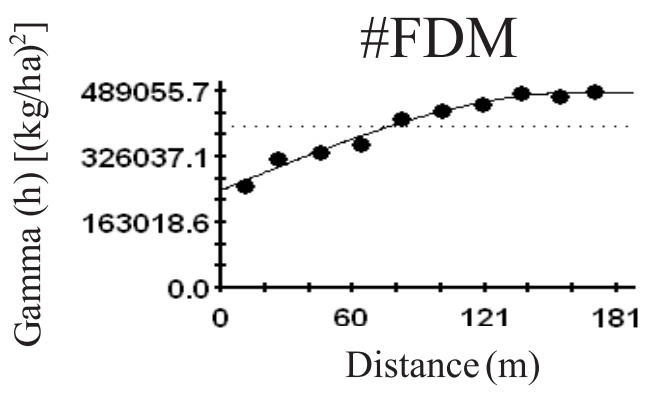

(a)
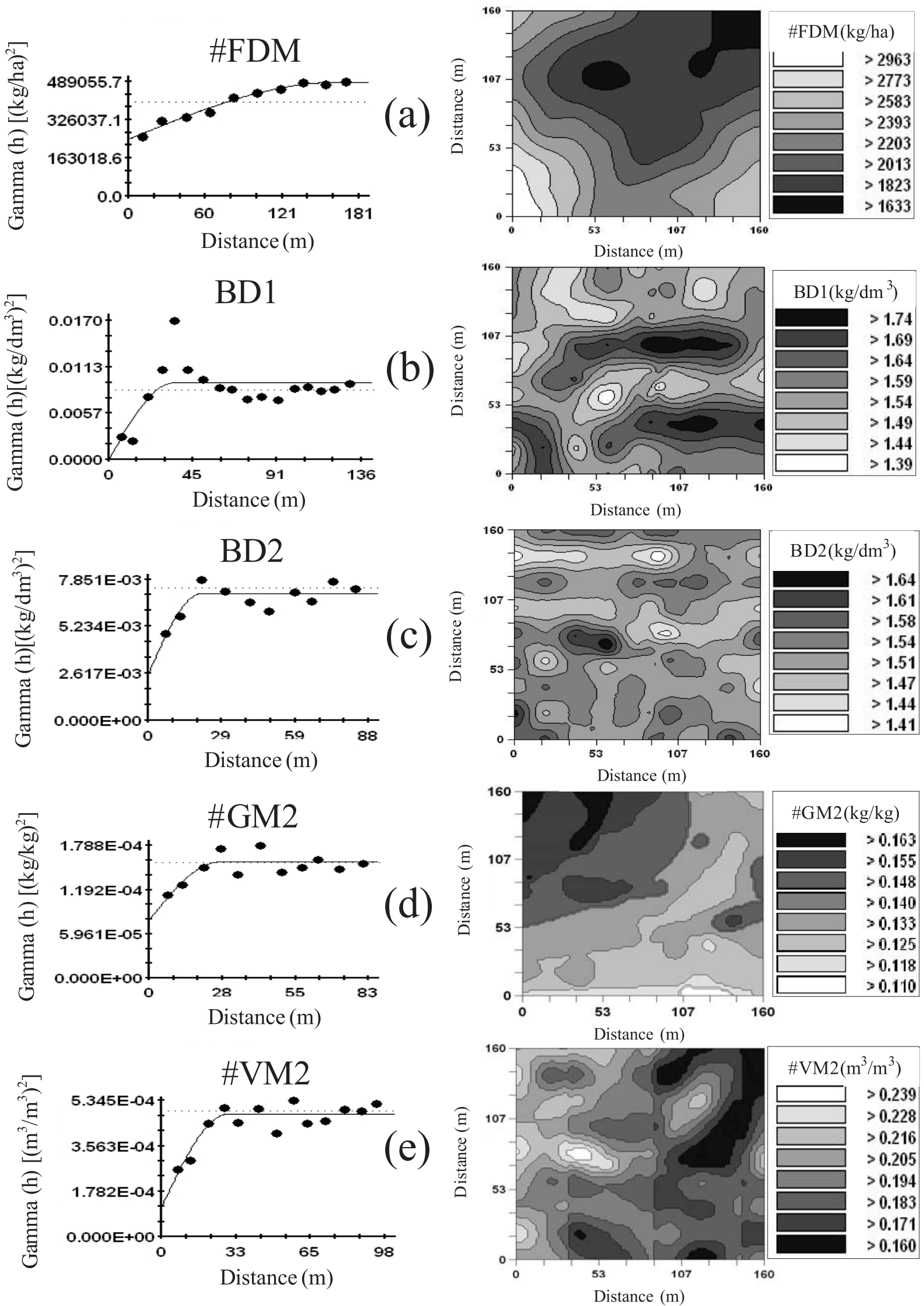

Figure 3 - Semivariograms and kriging maps of forage dry matter yield (\#FDM) for Brachiaria decumbens and some physical attributes (BD: bulk density; GM: gravimetric moisture; and VM: volumetric moisture, at depths 1 (0-0.10 m) and 2 (0.10-0.20 m) of a Red Latosol (Oxisol). 
Table 4 - Cross validation parameters with respect to krigings of forage dry matter yield for Brachiaria decumbens and some physical attributes of a Red Latosol (Oxisol)

\begin{tabular}{lll} 
Attribute $^{1}$ & Correlation coefficient $(r)$ & $\mathrm{OV}=\mathrm{a}+\mathrm{b} . \mathrm{EV}^{2}$ \\
\cline { 2 - 3 } & $\mathrm{A}$ & $\mathrm{b}$ \\
\hline
\end{tabular}

\begin{tabular}{lccc}
\hline & $\gamma(\mathrm{h})$ simple of plant attributes \\
\#FDM $(\mathrm{kg} / \mathrm{ha})$ & 0.276 & $-2.300 .10^{-1}$ & 0.772 \\
& $\gamma(\mathrm{h})$ & simple of soil physical attributes & \\
BD1 $\left(\mathrm{kg} / \mathrm{dm}^{3}\right)$ & 0.530 & $3.590 .10^{-1}$ & 0.773 \\
BD2 $\left(\mathrm{kg} / \mathrm{dm}^{3}\right)$ & 0.212 & $5.120 .10^{-1}$ & 0.512 \\
\#GM2 $(\mathrm{kg} / \mathrm{kg})$ & 0.055 & 0.000 & -0.167 \\
\#VM2 $\left(\mathrm{m}^{3} / \mathrm{m}^{3}\right)$ & 0.247 & 0.000 & 0.603 \\
\hline
\end{tabular}

${ }^{1}$ FDM: forage dry matter yield of Brachiaria decumbens; BD, GM and VM, from 1 to 2 are, respectively, bulk density, gravimetric moisture and volumetric moisture of soil, in depth $1(0-0.10 \mathrm{~m})$ and $2(0.10-0.20 \mathrm{~m})$.

2 OV: observed value; EV: estimate value.

in which only BD1 showed a higher correlation coefficient. However, in the remaining attributes (with the exception of gravimetric moisture at 0.10-0.20 m (\#GM2) - forage dry matter (\#FDM) yield, bulk density at 0.10-0.20 m(BD2) and volumetric moisture at 0.10-0.20 m (\#VM2) also showed satisfactory performance, with $r=0.276 ; 0.212$ and 0.247 , linear coefficient tending toward 0 and angular coefficient equal to $0.772,0.512$ and 0.603 , respectively.

\section{Conclusions}

With the exception of forage relative dry matter of Brachiaria decumbens and bulk density at both depths, the data of the other attributes showed medium to high variability, demonstrating a heterogeneous environment. Thus, the use of geostatistics emerges as an important tool to understand the interactions that take place in the pasture ecosystem, so as to reduce possible causes of degradation and indicate better soil-plant-animal handling alternatives. The reduction in forage dry matter yield of Brachiaria decumbens, combined with the increased bulk density at 0-0.10 m, appeared as an indicator of physical degradation (compaction) of a Red Latosol (Oxisol), especially in the regions with higher temporal concentration of animals and excessive trampling, in Cerrado conditions in the municipality of Selvíria, State of Mato Grosso do Sul.

\section{References}

ARSHAD, M.A.; LOWERY, B.; GROSSMAN, B. Physical tests for monitoring soil quality. In: DORAN, J.W.; JONES, A. (Eds.) Methods for assessing soil quality. Madison: Soil Science Society of America, 1996. p.123-141 (Special Publication, 49).

BAILEY, D.W. Identification and creation of optimum habitat conditions for livestock. Rangeland Ecology and Management, v.58, n.2, p.109-118, 2005.
BERTOL, I.; MAFRA, A.L.; COGO, N.P. Conservação do solo em pastagens. In: SIMPÓSIO SOBRE MANEJO DA PASTAGEM, 23., 2006, Piracicaba. Anais... Piracicaba: FEALQ, 2006. p.139-163.

CAMARGO, O.A.; ALLEONI, L.R.F. Compactação do solo e desenvolvimento das plantas. Piracicaba: ESALQ, 1997. 132p.

CANTARUTTI, R.B.; NASCIMENTO JÚNIOR, D.; COSTA, O.V. Impacto animal sobre o solo: compactação e reciclagem de nutrientes. In: MATTOS, W.R.S. (Ed.) A produção animal na visão dos brasileiros. Piracicaba: FEALQ, 2001. p.826-837.

CARVALHO, P.C.F.; TRINDADE, J.K.; MEZZALIRA, J.C. et al. Do bocado ao pastoreio de precisão: compreendendo a interface planta-animal para explorar a multi-funcionalidade das pastagens. Revista Brasileira de Zootecnia, v.38, supl., p.109-122, 2009.

CAVAlCANTE, E.G.S.; ALVES, M.C.; PEREIRA, G.T. et al. Variabilidade espacial de MO, P, K e CTC do solo sob diferentes usos e manejos. Ciência Rural, v.37, n.2, p.394-400, 2007.

CAVALLINI, M.C.; ANDREOTTI, M.; OLIVEIRA, L.L. et al. Relações entre produtividade de Brachiaria brizantha e atributos físicos de um Latossolo do Cerrado. Revista Brasileira de Ciência do Solo, v.34, n.4, p.1007-1015, 2010.

COLET, M.J.; SVERZUT, C.B.; WEIRICH NETO, P.H. et al. Alteração em atributos físicos de um solo sob pastagem após escarificação. Ciência e Agrotecnologia, v.33, n.2, p.361-368, 2009.

EMPRESA BRASILEIRA DE PESQUISA AGROPECUÁRIA Embrapa. Manual de métodos de análise do solo. 2.ed. Rio de Janeiro: CNPS, 1997. 212p.

EMPRESA BRASILEIRA DE PESQUISA AGROPECUÁRIA EMBRAPA. Sistema brasileiro de classificação de solos. 2.ed. Rio de Janeiro: CNPS, 2006. 306p.

GS+: Geostatistics for environmental sciences. 7.ed. Michigan, Plainwell: Gamma Desing Software, 2004.

HAKANSSON, I.; STENBERG, M.; RYDBERG, T. Long-term experiments with different depths of mouldboard ploughing in Sweden. Soil \& Tillage Research, 1998, v.46, n.3-4, p.209-223.

KIEHL, E.J. Manual de edafologia: relações solo-planta. Piracicaba: Agronômica Ceres, 1979. 264p.

LACA, E.A. Pastoreo de precisión. In: Bioma Campos: innovando para mantener su sustentabilidad y competitividad. Montevideo: Tradinco, 2008, v.1, p.29-40.

LIMA, C.G.R.; CARVALHO, M.P.; MELLO, M.M. et al. Correlação linear e espacial entre a produtividade de forragem, a porosidade total e a densidade do solo de Pereira Barreto (SP). Revista Brasileira de Ciência do Solo, v.31, n.6, p.1233-1244, 2007.

LIMA, J.S.S.; SATTLER, M.A.; PASSOS, R.R. et al. Variabilidade espacial de atributos físicos de um Argissolo Vermelho-Amarelo sob pastagem e vegetação secundária em regeneração natural. Engenharia Agrícola, v.29, n.2, p.185-195, 2009.

MARTINS, M.V.; CARVALHO, M.P.; ANDREOTTI, M. et al. Correlação linear e espacial entre a produtividade do feijoeiro e atributos físicos de um Latossolo Vermelho distroférrico de Selvíria, Estado de Mato Grosso do Sul. Acta Scientiarum. Agronomy, v.31, n.1, p.147-154, 2009.

PÁSCOA, A.G.; COSTA, M.J.R.P. Aplicação dos sistemas de informação geográfica para definição de estratégias de manejo de bovinos nas pastagens. Revista Brasileira de Zootecnia, v.36, supl., p.45-51, 2007.

REICHERT, J.M.; REINERT, D.J.; BRAIDA, J.A. Qualidade dos solos e sustentabilidade de sistemas agrícolas. Ciência \& Ambiente, v.27, p.29-48, 2003.

REICHERT, J.M.; SUZUKI, L.E.A.S.; REINERT, D.J. et al, Reference bulk density and critical degree-of-compactness for no-till crop production in subtropical highly weathered soils. Soil \& Tillage Research, v.102, n.2, p.242-254, 2009.

ROSA FILHO, G.; CARVALHO, M.P.; ANDREOTTI, M. et al. Variabilidade da produtividade da soja em função de atributos físicos de um Latossolo Vermelho distroférrico sob plantio direto. Revista Brasileira de Ciência do Solo, v.33, n.2, p.283-293, 2009. 
SANTOS, M.E.R.; FONSECA, D.M.; EUCLIDES, V.P.B. et al. Produção de bovinos em pastagens de capim-braquiária diferidas. Revista Brasileira de Zootecnia, v.38, n.4, p.635-642, 2009.

SANTOS, R.S.M.; OLIVEIRA, I.P.; MORAIS, R.F. et al. Componentes da parte aérea e raízes de pastagens de Brachiaria spp. em diferentes idades após a reforma, como indicadores de produtividade em ambiente de cerrado. Pesquisa Agropecuária Tropical, v.37, n.2, p.119-124, 2007.

SHAPIRO, S.S.; WILK, M.B. An analysis of variance test for normality (complete samples). Biometrika, v.52, n.3-4, p.591-611, 1965.

SILVA, G.J.; VALADÃO JÚNIOR, D.D.; BIANCHINI, A. et al. Variação de atributos físico-hídricos em latossolo vermelhoamarelo do cerrado mato-grossense sob diferentes formas de uso. Revista Brasileira de Ciência do Solo, v.32, n.5, p.2135-2143, 2008.

SPERA, S.T.; SANTOS, H.P.; FONTANELI, R.S. et al. Efeitos de sistemas de produção de grãos envolvendo pastagens sob plantio direto nos atributos físicos de solo e na produtividade. Revista Brasileira de Ciência do Solo, v.28, n.3, p.533-542, 2004.
STOLF, R. Teoria e teste experimental de fórmulas de transformação dos dados de penetrômetro de impacto em resistência do solo. Revista Brasileira de Ciência do Solo, v.15, n.2, p.229-235, 1991.

SULC, R.M.; TRACY, B.F. Integrated crop-livestock systems in the U.S. Corn Belt. Agronomy Journal, v.99, n.2, p.335-345, 2007.

TRACY, B.F.; ZHANG, Y. Soil compaction, corn yield response, and soil nutrient pool dynamics within an integrated crop-livestock system in Illinois. Crop Science, v.48, n.3, p.1211-1218, 2008.

van RAIJ, B.; CANTARELLA, H.; QUAGGIO, J.A. et al. (Eds.) Recomendação de adubação e calagem para o Estado de São Paulo. Campinas: IAC, 1997. 285p.

VIEIRA, J.C.; CAMPOS, M.C.; MARQUES JÚNIOR, J. et al. Variabilidade espacial da produção de matéria seca e resistência mecânica do solo a penetração em áreas cultivadas com capim braquiaria ("Brachiaria decumbens"). In: CONGRESSO INTERNACIONAL DE ZOOTECNIA - ZOOTEC, 7., 2005, Campo Grande. Anais... Campo Grande: ABZ/UEMS/UFMS, 2005. (CD-ROM).

WARREN, S.D.; NEVILL, M.B.; GARZA, N.E. Soil response to trampling under intensive rotation grazing. Soil Science Society of America Journal, v.50, n.5, p.1336-1341. 